Situs Jurnal : http://ejournal.stiepancasetia.ac.id/index.php/jieb

Jilid 6 Nomor 1 Maret 2020

Hal $84-98$

\title{
PENGARUH KONDISI FUNDAMENTAL DAN INFLASI TERHADAP HARGA SAHAM PADA PERUSAHAAN SUB SEKTOR PERKEBUNAN TAHUN 2016-2018.
}

\author{
Jumriaty Jusman, Sinta Devit Puspitasari \\ Sekolah Tinggi Ilmu Ekonomi Pancasetia, Jl. Ahmad Yani. Telp. (0511) 3256560 Fax. \\ (0511) 3256557 Banjarmasin - 70248
}

Abstrak: Penelitian ini bertujuan untuk mengetahui pengaruh faktor fundamental keuangan dan makroekonomi terhadap harga saham. Faktor fundamental keuangan yang digunakan dalam penelitian ini adalah ROA, CR dan EPS, sedangkan faktor makroekonomi yang digunakan ialah inflasi. Dengan menggunakan metode purposive sampling, didapatkan 7 perusahaan dari 18 perusahaan sub sektor perkebunan yang terdaftar di BEI selama periode 2016-2018. Data diolah dan dianalisis menggunakan analisis regresi linear berganda yang telah terlebih dulu melewati uji asumsi klasik seperti uji normalitas, multikolinearitas, heteroskedastisitas, dan autokorelasi. Hasil penelitian ini menunjukkan bahwa secara simultan ROA, CR, EPS, dan inflasi berpengaruh signifikan terhadap harga saham. Sedangkan secara parsial EPS berpengaruh signifikan terhadap harga saham, namun ROA, CR dan inflasi tidak berpengaruh signifikan terhadap harga saham.

Kata kunci: $R O A, C R$, EPS, Inflasi

\section{LATAR BELAKANG}

Pasar modal memiliki posisi sangat penting dalam perkembangan perekonomian Indonesia. Kemajuan teknologi serta tingginya arus globalisasi membuat pasar modal Indonesia dapat menjadi icon pasar modal Asia Tenggara. Perkembangan pasar modal tersebut tidak akan dapat terealisasikan apabila tidak ada dukungan dari pemerintah dan masyarakat bagi pasar modal Indonesia. Peran penting pasar modal bagi perekonomian suatu Negara dikarenakan pasar modal sebagai sarana pendanaan usaha atau sebagai sarana bagi perusahaan untuk mendapatkan dana dari masyarakat pemodal (investor). Dana yang diperoleh dari pasar modal dapat digunakan untuk pengembangan usaha, ekspansi, penambahan modal kerja dan lain-lain. Pasar modal menjadi sarana bagi masyarakat untuk berinvestasi pada instrumen keuangan seperti saham, obligasi, reksadana dan lain-lain. Dengan demikian masyarakat dapat menempatkan dana yang dimilikinya sesuai dengan karakteristik keuntungan dan risiko masing- masing instrumen.

Dalam menanamkan modalnya, investor akan mempertimbangkan dengan sebaikbaiknya ke perusahaan mana modal akan ditanamkan. Dalam kondisi ini setiap perusahaan dituntut untuk dapat beroperasi dengan tingkat efisiensi yang cukup tinggi agar tetap mempunyai keunggulan dan daya saing dalam upaya menghasilkan laba bersih seoptimal mungkin.

Saham sebagai salah satu instrumen investasi yang memiliki risiko paling tinggi. Investor bisa kehilangan semua modalnya apabila emiten bangkrut. Namun kejadian bangkrutnya emiten jarang terjadi. Investor selalu mencari alternatif investasi yang memberikan return tertinggi dengan tingkat risiko tertentu. Untuk melakukan investasi dalam bentuk saham diperlukan analisis untuk mengukur nilai saham, yaitu analisis fundamental dan analisis teknikal (Nirohito, 2009).

Analisis finamental adalah mencoba memperkirakan harga saham dimasa yang akan datang dengan mengestimasi faktor-faktor fundamental yang mempengaruhi harga saham di 
masa yang akan dating, dan menerapkan hubungan variabel-variabel tersebut sehingga diperoleh taksiran harga saham (Husnan,2005). Adapun pengertian analisis fundamental adalah analisis yang difungsikan untuk memperkirakan harga saham dimasa yang akan datang dengan mempertimbangkan faktor internal dan faktor eksternal sehingga mampu memperoleh taksiran harga saham.

Laporan keuangan merupakan salah satu sumber informasi yang pada umumnya digunakan oleh para investor maupun kreditur sebagai dasar keputusan penanaman modal maupun pemberian kredit. Tujuan umum dari laporan keuangan ini adalah untuk menyajikan informasi mengenai posisi keuangan, kinerja keuangan, dan arus kas dari entitas yang sangat berguna bagi pembuat keputusan ekonomi. Seorang investor menganalisa sebuah perusahaan dengan menggunakan analisa fundamental seperti data-data fundamental dan faktor faktor yang berhubungan dengan perusahaan yang dianalisis.Pada umumnya, faktor- faktor fundamental yang kerap diteliti untuk memprediksi harga saham atau return saham adalah nilai intrinsik, nilai pasar Return on Asset (ROA), Return On Investment (ROI) Return On Equity (ROE), Book Value (BV), Current Ratio (CR), Debt Equity Ratio (DER), Price Earning Ratio (PER), Devident Payout Ratio (DPR), dan Total Asset Turn Over (TATO).

Selain pertimbangan sisi fundamental keuangan perusahaan, investor juga perlu mempertimbangkan kondisi makroekonomi. Makroekonomi merupakan studi mengenai perekonomian suatu Negara secara menyeluruh, yang dipengaruhi oleh banyak variabel seperti income, pengangguran, inflasi, nilai tukar mata uang, Produk Domestik Bruto (PDB), politik, kebijakan pemerintah, bahkan kondisi perekonomian dunia. Persoalan yang timbul adalah sejauh mana perusahaan mampu mempengaruhi harga saham di pasar modal, dan faktor atau variabel apa saja yang dapat dijalankan sebagai indikator, sehingga memungkinkan perusahaan untuk mengendalikannya. Pada akhirnya tujuan untuk meningkatkan nilai perusahaan melalui peningkatan nilai saham yang diperdagangkan di pasar modal dapat dicapai. Dalam rangka inilah penelitian dilakukan, walaupun disadari bahwa faktor-faktor fundamental sangat luas dan cakupannya tidak saja meliputi kondisi internal perusahaan (basic financial dan economic facts), tetapi juga kondisi fundamental makro yang berada di luar kendali perusahaan. Sedangkan dalam penelitian ini dibatasi hanya menganalisis faktor-faktor fundamental perusahaan yaitu Return on Asset (ROA), dan Debt Equity Ratio (DER), sedangkan pada faktor Makro yaitu inflasi.

Objek yang digunakan dalam penelitian ini adalah perusahaan sektor perkebunan. Perusahaan sektor ini dipilih menjadi objek penelitian karena sektor ini mengalami perkembangan diakibatkan oleh kebijakan pemerintah. Pada penutupan perdagangan Jumat 10 Januari 2020, Indeks Harga Saham Gabungan (IHSG) menguat tipis 0,01\% ke level 6.274,49. Pada sektor perkebunan berada di urutan kedua di zona merah yang turun 0,59\%. Namun sehari sebelumnya pada hari Kamis sektor perkebunan yang naik 3,77\%. Terkait hal itu, ada beberapa katalis positif yang membuat sektor perkebunan melesat. Salah satunya setelah diterapkan mandatory B20 mulai 1 september 2018, kini pemerintah mengadakan percepatan implementasi B30. Selain itu Malaysia juga ada kebijakan mencampur 20\% minyak sawit ke bahan bakar solar atau B20. Perdana Menteri Malaysia yang memberi pernyataan kontroversial mengenai mengenai Kashmir membuat para pembeli minyak sawit dari India mencari suplai dari negara lain, termasuk Indonesia (kontan.co.id). Oleh karena itu, saham-saham yang berkaitan dengan crude palm oil (CPO) saat ini menarik untuk dikoleksi para investor. 


\section{KAJIAN LITERATUR}

\section{Pengaruh Kondisi Fundamental Perusahaan Terhadap Harga Saham}

Analisis fundamental merupakan analisis yang digunakan untuk mencoba memperkirakan harga saham di masa yang akan datang dengan mengestimasi nilai faktorfaktor fundamental yang mempengaruhi harga saham di masa yang akan datang, dan menerapkan hubungan-hubungan variabel-variabel tersebut sehingga diperoleh taksiran harga saham. Analisis fundamental adalah metode dalam melakukan analisis informasi, melakukan proyeksi dari informasi tersebut guna menghasilkan penilaian yang tepat bagi perusahaan. Menurut Sutrisno (2005) analisis fundamental adalah pendekatan analisis harga saham yang berfokus pada kinerja perusahaan yang menerbitkan saham dan analisis ekonomi yang akan mempengaruhi masa depan perusahaan. Analisis fundamental berfokus pada rasio keuangan dan peristiwa yang secara langsung atau tidak langsung mempengaruhi kinerja keuangan perusahaan. Beberapa ahli berfikir teknik analisis fundamental lebih cocok untuk membuat keputusan dalam memilih saham perusahaan yang dibeli untuk jangka panjang.

Selain kondisi fundamental perusahaan, menurut Fahmi (2012) efek dari makro ekonomi juga berimbas pada harga saham. Kondisi ekonomi makro juga memiliki dampak langsung terhadap naik turunnya harga saham. Naik turunnya suku bunga yang diakibatkan kebijakan bank sentral Amerika (Federal Reserve) dan juga naik turunnya suku Bunga acuan Bank Indonesia (BI) dan nilai ekspor impor yang berakibat lamgsung pada nilai tukar rupiah terhadap AS. Tingkat inflasi juga termasuk dalam salah satu faktor kondisi ekonomi makro. Selanjutnya dalam penelitian ini, peneliti hanya menggunakan analisis faktor fundamental adalah rasio Return on Asset (ROA), Current Ratio (CR), Earning Per Share (EPS) sedangkan pada faktor Makro yaitu inflasi.

Return on Asset (ROA) digunakan untuk mengukur efektivitas perusahaan di dalam menghasilkan keuntungan dengan memanfaatkan aktiva yang dimilikinya. Semakin tinggi ROA berarti kinerja perusahaan semakin efektif, karena tingkat kembalian akan semakin besar (Brigham dan Houston, 2001). Pengukuran kinerja keuangan perusahaan dengan ROA menunjukkan kemampuan atas modal yang diinvestasikan dalam keseluruhan aktiva yang dimiliki untuk menghasilkan laba. Semakin besar ROA akan menggambarkan bahwa kinerja perusahaan semakin baik dan pemegang saham akan mendapatkan keuntungan dividen yang diterima semakin meningkat. ROA yang semakin tinggi akan meningkatkan harga saham. Perusahaan dengan ROA yang besar akan meningkatkan minat calon investor untuk menanamkan dananya di perusahaan tersebut sehingga selanjutnya akan berdampak pada kenaikkan harga saham karena bertambahnya permintaan terhadap saham perusahaan tersebut. Oleh karena itu, secara teoritis ROA memiliki pengaruh yang positif terhadap harga saham.Hal ini didukung oleh penelitian sebelumnya yang telah dilakukan oleh Wardani dan Andarini (2016) yang menunjukkan bahwa Return on Asset (ROA) dan Debt Equity Ratio (DER) secara parsial berpengaruh positif terhadap harga saham. Pada penelitian Anastasia,Gunawan \% Wijiyanti (2003) Secara empiris terbukti bahwa faktor fundamental (ROA,ROE,BV,DER,r) dan risiko sistematik (beta) mempunyai pengaruh yang signifikan terhadap harga saham perusahaan properti secara bersama-sama.

H1 : Return on Asset (ROA) berpengaruh signifikan terhadap harga saham.

Current Ratio (CR) atau rasio lancar adalah salah satu jenis rasio likuiditas. Rasio likuiditas menunjukkan atau mengukur kemampuan perusahaan dalam memenuhi kewajiban yang sudah jatuh tempo, baik kewajiban kepada pihak luar perusahaan maupun di dalam perusahaan (Kasmir, 2008). Current Ratio menunjukkan sampai sejauh mana kewajiban lancar 
ditutupi oleh asset yang diharapkan akan dikonversi menjadi kas dalam waktu dekat. Semakin tinggi rasio nilai Current Ratio (CR) memberikan gambaran semakin baik kemampuan perusahaan untuk melunasi kewajibannya berarti semakin kecil risiko likuiditas yang dialami perusahaan dan semakin kecil risiko yang ditanggung pemegang saham perusahaan. Informasi peningkatan Current Ratio (CR) akan diterima pasar sebagai sinyal baik yang akan memberikan masukan positif bagi investor dalam keputusan membeli saham. Hal ini juga memberikan keyakinan kepada investor terhadap kemampuan perusahaan untuk membayar deviden, sehingga secara teoritis Current Ratio (CR) memberi pengaruh secara positif terhadap harga saham. Hal ini didukung oleh penelitian Setiyawan (2014) yang menyatakan bahwa Current Ratio (CR) berpengaruh positif terhadap harga saham pada Perusahaan Manufaktur yang terdaftar di BEI tahun 2009-2012, pada penelitian lain juga menyatakan bahwa current ratio berpengaruh positif dan signifikan terhadap harga saham Prihantini (2009).

H2 : Current Ratio (CR) berpengaruh signifikan terhadap harga saham.

Earning Per Share (EPS) menunjukkan besarnya laba bersih perusahaan yang siap dibagikan bagi semua pemegang saham perusahaan (Tandelilin: 2010). Earning Per Share (EPS) merupakan indikator yang menunjukkan kemampuan perusahaan untuk memberikan imbalan (return) pada setiap lembar saham biasa. Pemberian saham biasa umumnya lebih memperhatikan penghasilan per lembar saham dari pada dividen yang diperoleh. Biasanya penghasilan per lembar saham biasa mempengaruhi harga saham di bursa efek. Secara sederhana Earning per share (EPS) menggambarkan jumlah uang yang diperoleh untuk setiap lembar saham. Jika kemampuan perusahaan untuk menghasilkan laba meningkat maka harga saham meningkat. (Rahardjo,2009:150) Peningkatan pada Earning Per Share (EPS) akan membuat pasar memiliki reaksi yang positif hal ini dikarnakan peningkatan Earning Per Share (EPS) dianggap sebagai sinyal terhadap prosfek perusahaan dimasa yang akan datang. Demikian juga sebaliknya pasar akan memiliki reaksi yang negatif jika terjadi penurunan Earning Per Share (EPS) yang dianggap sebagai sinyal yang kurang baik terhadap prosfek perusahaan dimasa yang akan datang. Earning Per Share dalam laporan keuangan sering digunakan oleh manajemen untuk menarik perhatian calon investor sehingga Earning Per Share (EPS) tersebut sering direkayasa sedemikian rupa oleh pihak manajemen untuk mempengaruhi keputusan akhir pihak-pihak tertentu. Dengan demikian apabila harga saham perusahaan meningkat maka return yang akan diperoleh investor juga akan semakin tinggi. Kenaikan earning per share berarti perusahaan sedang dalam tahap pertumbuhan atau kondisi keuangannya sedang mengalami peningkatan dalam penjualan dan laba, atau dengan kata lain semakin besar earning per share menandakan kemampuan perusahaan dalam menghasilkan keuntungan bersih setiap lembar saham. Pernyataan tersebut diperkuat oleh hasil penelitian dari Siti Marfuatun dan Iin Indarti (2012) bahwa EPS berpengaruh positif dan signifikan terhadap harga saham. Pada penelitian lain juga yang dilakukan Dewi dan Suaryana (2013) menyatakan bahwa dengan bahwa Earning per share (EPS) terbukti mempunyai pengaruh signifikan dan positif terhadap harga saham perusahaan emiten bidang Food and Beverage.

H3 : Earning Per Share (EPS) berpengaruh signifikan terhadap harga saham.

\section{Pengaruh Inflasi Terhadap Harga Saham}

Menurut Case, Fair, dan Oster (2012), Inflasi adalah keadaan dimana harga-harga barang dan jasa meningkat secara cepat, bukan hanya peningkatan harga barang- barang tertentu, tetapi barang secara keseluruhan. Tingkat inflasi yang tinggi biasanya dikaitkan dengan kondisi ekonomi yang terlalu panas (overheated). Artinya permintaan atas produk yang melebihi kapasitas penawaran produknya, sehingga harga cenderung mengalami kenaikan. Inflasi 
berdampak pada penurunan daya beli masyarakat dan pendapatan riil investor menjadi turun. Tingginya tingkat inflasi akan meningkatkan biaya hidup dan pergeseran sumber daya dari investasi ke konsumsi. Hal ini menyebabkan turunnya permintaan instrument pasar sehingga menurukan volume saham yang diperdagangkan (Kuwornu, 2012). Ukuran Inflasi yang paling banyak adalah digunakan adalah Consumer Price Indeks. Perubahan CPI dari waktu ke waktu menunjukkan pergerakan harga dari paket barang dan jasa yang dikonsumsi masyarakat. Penentuan barang dan jasa dilakukan atas dasar Survei Biaya Hidup (SBH) yang dilaksanakan oleh Badan Pusat Statistik (BPS). Inflasi merupakan faktor makro ekonomi yang mampu menguntungkan sekaligus merugikan perusahaan. Pada dasarnya inflasi yang tinggi tidak disukai oleh pelaku pasar modal karena akan meningkatkan biaya produksi dan biaya operasional perusahaan. Tetapi disisi lain inflasi juga akan meningkatkan harga jual produk perusahaan tersebut (Andes et. al, 2017).

Tingkat inflasi mempengaruhi secara signifikan terhadap harga saham. Peningkatan inflasi secara relatif merupakan sinyal negatif bagi pemodal di pasar modal. Inflasi meningkatkan pendapatan dan biaya perusahaan. Jika peningkatan biaya produksi lebih tinggi dari peningkatan harga yang dapat dinikmati oleh perusahaan maka profitabilitas perusahaan akan turun. Jika profit yang diperoleh perusahaan kecil, hal ini akan mengakibatkan para investor enggan menanamkan dananya di perusahaan tersebut sehingga harga saham menurun dan return yang akan diperoleh juga menurun. . Oleh karena itu, secara teoritis Inflasi berpengaruh negatif dan signifikan terhadap harga saham. Hal tersebut didukung oleh hasil penelitian Wardani dan Andarini (2016) bahwa Current Ratio, Total Asset Turn Over, dan Inflasi tidak berpengaruh terhadap harga saham. Serta hasil penelitian Husnul dkk (2017) menyatakan bahwa variabel inflasi Indonesia tidak berpengaruh signifikan terhadap IHSG di BEI.

H4 : Inflasi tidak berpengaruh signifikan terhadap harga saham.

\section{METODE PENELITIAN \\ Populasi dan Sampel}

Populasi dalam penelitian ini adalah 18 perusahaan sub sektor perkebunan yang terdaftar di Bursa Efek Indonesia selama periode penelitian (2016-2018). Pemilihan sampel dengan menggunakan metode purposive sampling yang terdiri dari kriteria-kriteria sebagai berikut: 1). Perusahaan sub sektor perkebunan yang tercatat pada BEI selama periode penelitian yaitu Januari 2016 sampai dengan Desember 2018, 2). Perusahaan sub sektor perkebunan yang tercatat pada BEI dengan bidang usaha perkebunan kelapa sawit 3). Laporan keuangan merupakan laporan keuangan tahunan, hal ini menghindari adanya pengaruh parsial dalam perhitungan rasio, 4). Perusahaan yang diteliti mencatatkan laba selama periode penelitian, dan 5). Data tersedia untuk dapat dilakukan dianalisis. Berdasarkan kriteria tersebut, terdapat 7 perusahaan memenuhi kriteria. Adapun nama-nama perusahaan yang telah memenuhi kriteria tersebut yaitu, PT. Astra Agro Lestari,Tbk, PT Dharma Satya Nusantara, Tbk, PP London Sumatra Indonesia, Tbk, PT Sampoerna Agro, Tbk, PT. Sinar Mas Agro Resources and Technology, Tbk, PT. Sawit Sumbermas Sarana, Tbk, dan PT. Tunas Baru Lampung, Tbk.

\section{Variabel Penelitian}

Dalam penelitian ini yang menjadi variabel dependen adalah harga saham. Menurut Jogiyanto (2008), harga saham adalah harga suatu saham yang terjadi di pasar bursa pada saat tertentu yang ditentukan oleh pelaku pasar dan ditentukan oleh permintaan dan penawaran saham yang bersangkutan di pasar modal. Harga saham yang digunakan dalam penelitian ini ialah harga penutupan pada akhir tahun $2016-2018$. 
Sedangkan yang menjadi variabel Independen dalam penelitian ini adalah Return on Asset (ROA), Current Ratio (CR), Earning Per Share (EPS) dan Inflasi.

1. Return on Asset (ROA) merupakan rasio yang mengukur kemampuan perusahaan menghasilkan laba dengan menggunakan total assets (kekayaan) yang dimiliki perusahaan setelah disesuaikan dengan biaya-biaya untuk menandai assets tersebut (Hanafi, 2005). Besarnya ROA dapat dihitung dengan rasio antara laba bersih setelah pajak terhadap total assets, sehingga secara matematis ROA dapat dirumuskan sebagai berikut :

$$
R O A=\frac{\text { Net Income After Tax }}{\text { Total Assets }}
$$

2. Current Ratio (CR), atau rasio lancar merupakan rasio untuk mengukur kemampuan perusahaan dalam membayar kewajiban jangka pendek atau utang yang segera jatuh tempo pada saat ditagih secara keseluruhan (Kasmir:2016). Secara matematis CR dapat dirumuskan sebagai berikut :

$$
C R=\frac{\text { Current Assets }}{\text { Current Liability }}
$$

3. Earning Per Share (EPS) menunjukkan besarnya laba bersih perusahaan yang siap dibagikan bagi semua pemegang saham perusahaan (Tandelilin: 2010). EPS dapat dirumuskan sebagai barikut :

$$
E P S=\frac{\text { Laba Bersih Setelah Pajak }}{\text { Jumlah Saham Yang Beredar }}
$$

4. Inflasi merupakan prosentase kenaikan harga barang-barang yang terjadi secara terus menerus dalam suatu negara. Inflasi diukur dengan menggunakan indikator Indeks Harga Konsumen (IHK), di mana mencerminkan pergerakan harga-harga dari paket barang dan jasa yang dikonsumsi masyarakat.

\section{Sumber dan Teknik Pengumpulan Data}

$$
\text { Inflasi }=\frac{I H K_{n}-I H K_{n-1}}{I H K_{n-1}} \times 100 \%
$$

Penelitian ini menggunakan teknik pengumpulan yang didasarkan pada pengumpulan data sekunder atau dengan kata lain menggunakan metode dokumenter. Data sekunder berupa rasio-rasio keuangan seperti Return on Asset (ROA), Debt to Equity Ratio (DER) dan Inflasi. Data laporan keuangan dan pergerakan harga saham diperoleh dari website masing-masing perusahaan atau situs BEI (www.idx.co.id), sedangkan data inflasi diperoleh dari situs Badan Pusat Statistik (www.bps.go.id).

\section{Rencana Analisis Data}

1. Uji Asumsi Klasik

Sebelum melakukan analisis regresi, peneliti melakukan uji asumsi klasik yang terdiri atas uji normalitas, uji heteroskedastisitas, uji multikolinieritas dan uji autokorelasi yang diolah dengan menggunakan (Statistical Package for the Social Sciences )SPSS v25.

Uji Normalitas adalah untuk melihat apakah nilai residual terdistribusi normal atau tidak, dimana Model regresi yang baik adalah memiliki nilai residual yang terdistribusi normal (Sutopo \& Slamet :2017). Pada penelitian ini uji normalitas bukan dilakukan pada masing- masing variabel akan tetapi pada nilai residualnya.

Uji Heteroskedastisitas digunakan untuk melihat apakah terdapat ketidaksamaan varian dari residual satu ke pengamatan ke pengamatan yang lain. Model regresi yang memenuhi persyaratan adalah di mana terdapat kesamaan varian dari residual satu pengamatan ke pengamatan yang lain tetap atau disebut homoskedastisitas (Sutopo \& 
Slamet :2017). Pada penelitian ini uji heteroskedastisitas dilakukan dengan uji Park dimana pengujian dilakukan dengan meregresikan nilai log residual kuadrat sebagai variabel dependen dengan variabel independen.

Uji Multikolinieritas adalah untuk melihat ada atau tidaknya korelasi yang tinggi antara variabel- veriabel bebas dalam suatu model regresi linier berganda, dimana hubungan antara variabel bebas terhadap variabel terikatnya menjadi terganggu, jika ada korelasi yang tinggi di antara variabel-variabel bebasnya (Sutopo \& Slamet :2017). Prasyarat yang harus terpenuhi dalam model regresi adalah tidak terjadinya gejala multikolinieritas.

Uji Autokorelasi adalah untuk melihat apakah terjadi korelasi antara suatu periode $\mathrm{t}$ dengan periode sebelumnya ( $\mathrm{t}-1)$, dimana Uji Autokorelasi hanya dilakukan pada data time series dan tidak perlu dilakukan pada data cross section (Sutopo \& Slamet :2017). Pada penelitian ini Uji Autokorelasi dilakukan dengan menngunakan uji Run Test.

2. Analisis Regresi Linier Berganda

Menurut Priyatno (2008), analisis regresi berganda menunjukkan hubungan secara linier antara dua atau lebih variabel independen terhadap variabel dependennya. Analisis ini digunakan untuk mengetahui arah hubungan variabel independen terhadapa variabel dependen, apakah positif atau negatif. Selain itu juga untuk memprediksi nilai variabel dependen jika terjadi penurunan atau peningkatan pada variabel indepennya.

3. Uji t

Uji t dilakukan untuk mengetahui bagaimana pengaruh variabel independen secara parsial terhadap variabel dependen yang diuji pada tingkat signifikansi 0,05 . Suatu variabel independen dapat dikatakan memiliki pengaruh yang signifikan terhadap variabel dependen jika nilai signifikansi di bawah 0,05 .

4. Uji F

Uji F dilakukan untuk mengetahui apakah semua variabel independen secara simultan berpengaruh terhadap variabel dependen dengan nilai signifikansi 0,05 . Semua variabel independen dapat dikatakan berpengaruh signifikan terhadap variabel dependennya jika nilai signifikansi di bawah 0,05 .

5. Koefisien Determinasi $\left(\mathrm{R}^{2}\right)$

Menurut Santosa dan Ashari (2005), koefisien determinasi adalah suatu nilai yang menggambarkan seberapa besar perubahan atau variasi variabel independen mampu mencerminkan perubahan atau variasi variabel dependen. Semakin tinggi nilai koefisien determinasi, maka semakin baik kemampuan variabel independen menjelaskan perilaku variabel dependen. Untuk menghindari terjadinya kenaikan bias atau kesalahan karena kenaikan jumlah variabel dan jumlah sampel, maka lebih baik menggunakan koefisien determinasi yang telah disesuaikan (adjusted $R$ square) - hasil penyesuaian koefisien determinasi terhadap tingkat kebebasan dari persamaan prediksi.

\section{HASIL PENELITIAN}

\section{Uji Asumsi Klasik}

1. Uji Normalitas yang digunakan pada penelitian ini yaitu uji statistik Kolmogorov Smirnov Test (K-S) pada nilai unstandardized residual (RES_1) untuk persamaan regresi pengaruh ROA, CR, EPS dan Inflasi terhadap harga saham pada perusahaan sub sektor perkebunan tahun 2016-2018. Adapun data dinyatakan berdistribusi normal jika signifikansi (Sig) lebih besar dari 0,05 .

\section{Tabel 1. Hasil uji normalitas}




\section{One-Sample Kolmogorov-Smirnov Test}

\begin{tabular}{llr} 
& & \multicolumn{2}{c}{$\begin{array}{c}\text { Unstandardized } \\
\text { Residual }\end{array}$} \\
\hline $\mathrm{N}$ & & 21 \\
\hline Normal Parameters ${ }^{\mathrm{a}, \mathrm{b}}$ & Mean & .0000000 \\
\cline { 2 - 3 } & $\begin{array}{l}\text { Std. } \\
\text { Deviation }\end{array}$ & \\
\hline Most Extreme & Absolute & .1611 .73733973 \\
\cline { 2 - 3 } Differences & Positive & .093 \\
\cline { 2 - 3 } & Negative & -.169 \\
\hline Test Statistic & & .169 \\
\hline Asymp. Sig. (2-tailed) & & $.120^{\mathrm{c}}$ \\
\hline $\begin{array}{l}\text { a. Test distribution is Normal. } \\
\text { b. Calculated from data. } \\
\text { c. Lilliefors Significance Correction. }\end{array}$ &
\end{tabular}

\section{Sumber : Data diolah, 2020}

Dari hasil tabel 1 uji normalitas Kolmogorov Smirnov dapat disimpulkan bahwa data berdistribusi normal, dilihat dari nilai signifikansi sebesar 0,120 yang berarti lebih besar dari nilai alpha 0,05 .

2. Uji Heteroskedastisitas yang digunakan pada penelitian ini yaitu melalui uji Park. Sebelum melakukan pengujian, maka perlu dilakukan transformasi ke dalam bentuk logaritma natural nilai residual yang telah dikuadratkan $\left(\mathrm{LN} \mathrm{RES}^{2}\right)$, sedangkan variabelvariabel independen di transformasi dalam bentuk logaritma natural. Adapun dasar pengambilan keputusan yaitu jika nilai signifikansi (Sig) $>0,05$ maka tidak terjadi gejala heterokedastisitas begitupun sebaliknya jika signifikansi (Sig) $<0,05$.

\section{Tabel 2. Hasil uji heteroskedastisitas}

\begin{tabular}{|c|c|c|c|c|c|c|}
\hline & & & Coefficients & & & \\
\hline & & $\begin{array}{r}\text { Unstand } \\
\text { Coeffi }\end{array}$ & $\begin{array}{l}\text { ardized } \\
\text { ients }\end{array}$ & $\begin{array}{l}\text { Standardized } \\
\text { Coefficients }\end{array}$ & & \\
\hline & & $\mathrm{B}$ & Std. Error & Beta & $\mathrm{t}$ & Sig. \\
\hline 1 & (Constant) & 18.259 & 5.829 & & 3.133 & .006 \\
\hline & ROA & .415 & .233 & .495 & 1.783 & .094 \\
\hline & $\mathrm{CR}$ & .002 & .003 & .146 & .789 & .442 \\
\hline & EPS & .002 & .001 & .332 & 1.416 & .176 \\
\hline & INFLASI & -2.342 & 1.822 & -.295 & -1.285 & .217 \\
\hline
\end{tabular}

a. Dependent Variable: LnRes_2

\section{Sumber : Data diolah, 2020}

Dari hasil tabel 2 uji heteroskedastisitas dengan menggunakan uji park di atas menunjukkan bahwa tidak terjadinya gejala heteroskedastisitas, hal ini dapat terlihat dari nilai signifikansi semua variabel independen $>0,05$. 
3. Pada penelitian ini metode pengujian multikolinearitas yang digunakan yaitu dengan melihat nilai inflation factor (VIF) setiap variabel pada model regresi. Jika nilai VIF < 10,00 maka tidak terjadi multikolinearitas. Sebaliknya Jika nilai VIF > 10,00 maka terjadi multikolinearitas.

Tabel 3. Hasil uji multikolinieritas

\begin{tabular}{|c|c|c|c|c|c|c|c|c|}
\hline \multirow[b]{3}{*}{ Model } & \multicolumn{8}{|c|}{ Coefficients $^{\mathbf{a}}$} \\
\hline & & \multicolumn{2}{|c|}{$\begin{array}{l}\text { Unstandardized } \\
\text { Coefficients }\end{array}$} & \multirow[t]{2}{*}{$\begin{array}{l}\text { Standardize } \\
\text { d } \\
\text { Coefficient } \\
\text { s }\end{array}$} & \multirow[b]{2}{*}{$\mathrm{t}$} & \multirow[b]{2}{*}{ Sig. } & \multicolumn{2}{|c|}{$\begin{array}{c}\text { Collinearity } \\
\text { Statistics }\end{array}$} \\
\hline & & B & $\begin{array}{c}\text { Std. } \\
\text { Error }\end{array}$ & & & & $\begin{array}{l}\text { Toler } \\
\text { ance }\end{array}$ & VIF \\
\hline 1 & $\begin{array}{l}\text { (Constant } \\
\text { ) }\end{array}$ & 924.467 & $\begin{array}{r}6278.08 \\
4 \\
\end{array}$ & & .147 & .885 & & \\
\hline & ROA & -390.610 & 250.843 & -.232 & $\begin{array}{r}- \\
1.557\end{array}$ & .139 & .444 & 2.254 \\
\hline & $\mathrm{CR}$ & 2.968 & 3.208 & .092 & .925 & .369 & .993 & 1.007 \\
\hline & EPS & 12.766 & 1.557 & 1.030 & 8.200 & .000 & .624 & 1.602 \\
\hline & INFLASI & 226.076 & $\begin{array}{r}1962.88 \\
8 \\
\end{array}$ & .014 & .115 & .910 & .651 & 1.536 \\
\hline
\end{tabular}

a. Dependent Variable: HARGA SAHAM

\section{Sumber : Data diolah, 2020}

Berdasarkan Tabel 3 Uji Multikolinieritas di atas, diperoleh nilai VIF semua varibel Independen lebih kecil dari 10,00 (VIF < 10,00), hal tersebut menunjukkan bahwa tidak terjadi gejala multikolinieritas.

4. Uji Autokorelasi yang digunakan pada penelitian ini yaitu dengan uji Run Test. Dasar pengambilan keputusan dalam uji Run Test adalah jika nilai Asyimp.Sig (2-tailed) lebih kecil dari 0,05 maka terdapat gejala autokorelasi, sebaliknya jika nilai Asyimp.Sig (2tailed) lebih besar dari 0,05 maka tidak terdapat gejala autokorelasi.

Tabel 4. Hasil uji autokorelasi

\section{Runs Test}

\begin{tabular}{lr} 
& $\begin{array}{c}\text { Unstandardize } \\
\text { d Residual }\end{array}$ \\
\hline Test Value & 267.56483 \\
\hline Cases < Test Value & 10 \\
\hline Cases > = Test Value & 11 \\
\hline Total Cases & 21 \\
\hline Number of Runs & 10 \\
\hline$Z$ & -.438 \\
\hline Asymp. Sig. (2- & .661 \\
tailed) & \\
\hline
\end{tabular}


a. Median

Sumber : Data diolah, 2020

Berdasarkan tabel 4 hasil uji autokorelasi di atas diketahui nilai Asymp. Sig. (2tailed) sebesar 0,661 lebih besar dari 0,05, maka dapat disimpulkan bahwa tidak terdapat gejala atau masalah autokorelasi.

\section{Regresi Linier Berganda}

Tabel 5. Hasil regresi linier berganda

\begin{tabular}{|c|c|c|c|c|}
\hline \multirow{2}{*}{\multicolumn{2}{|c|}{ Model }} & \multicolumn{2}{|c|}{$\begin{array}{l}\text { Unstandardized } \\
\text { Coefficients }\end{array}$} & \multirow{2}{*}{$\begin{array}{c}\text { Standardized } \\
\text { Coefficients } \\
\text { Beta } \\
\end{array}$} \\
\hline & & $\mathrm{B}$ & Std. Error & \\
\hline \multirow[t]{5}{*}{1} & (Constant) & 924.467 & 6278.084 & \\
\hline & $\mathrm{ROA}$ & -390.610 & 250.843 & -.232 \\
\hline & $\mathrm{CR}$ & 2.968 & 3.208 & .092 \\
\hline & EPS & 12.766 & 1.557 & 1.030 \\
\hline & INFLASI & 226.076 & 1962.888 & .014 \\
\hline
\end{tabular}

a. Dependent Variable: HARGA SAHAM

Sumber : Data diolah, 2020

Berdasarkan Tabel 5, maka persamaan regresi linear bergandanya adalah: Inflasi.

Harga Saham = 924,467- -390,610 ROA + 2,968 CR + 12,766 EPS + 226,076

Penjelasan mengenai persamaan regresi linear berganda ialah:

1. Konstanta sebesar 924,467, artinya jika ROA, CR, EPS dan inflasi nilainya 0 (nol), maka harga saham nilainya adalah sebesar 924,467.

2. Koefisien regresi ROA sebesar - 390,610, artinya jika variabel independen lainnya tetap dan ROA naik 1\%, maka harga saham akan mengalami penurunan sebesar Rp. 390,610.

3. Koefisien regresi CR sebesar 2,968, artinya jika nilai variabel independen lainnya tetap dan CR mengalami kenaikan 1\%, maka harga saham akan mengalami kenaikan sebesar Rp. 2,968 .

4. Koefisien regresi EPS sebesar 12,766, artinya jika nilai variabel independen lainnya tetap dan EPS mengalami kenaikan 1\%, maka harga saham akan mengalami kenaikan sebesar Rp. 12,766.

5. Koefisien regresi inflasi sebesar 226,076, artinya jika variabel independen lainnya tetap dan inflasi naik 1\%, maka harga saham akan mengalami kenaikan sebesar Rp. 226,076.

Uji Signifikansi Simultan (Uji F)

Tabel 6. Hasil uji F

\begin{tabular}{|c|c|c|c|c|c|c|}
\hline & & & JOVA ${ }^{a}$ & & & \\
\hline Model & & $\begin{array}{l}\text { Sum of } \\
\text { Squares }\end{array}$ & $\mathrm{df}$ & Mean Square & $\mathrm{F}$ & Sig. \\
\hline 1 & Regression & 350723760.0 & 4 & 87680940.01 & 21.370 & $.000^{\mathrm{b}}$ \\
\hline & & 46 & & 1 & & \\
\hline & Residual & $\begin{array}{r}65647843.76 \\
4\end{array}$ & 16 & 4102990.235 & & \\
\hline
\end{tabular}




\begin{tabular}{rr|r|r|r}
\hline Total & 416371603.8 & 20 & & \\
& 10 & & & \\
\hline
\end{tabular}

a. Dependent Variable: HARGA SAHAM

b. Predictors: (Constant), INFLASI, CR, EPS, ROA

\section{Sumber : Data diolah, 2020}

Uji signifikansi simultan atau biasa disebut uji $\mathrm{F}$ dilakukan untuk mengetahui pengaruh variabel-variabel independen secara simultan/ bersamaan terhadap variabel dependennya. Hasil uji F dalam Tabel 6 menampilkan bahwa nilai signifikansi sebesar 0,000 lebih kecil dibanding dengan nilai alpha sebesar 0,05, maka dapat disimpulkan bahwa Ho ditolak, dan Ha diterima. Hal ini berarti bahwa ROA, CR, EPS dan Inflasi secara simultan berpengaruh terhadap harga saham. Hal tersebut menunjukkan Bahwa secara bersama-sama variabel ROA, CR, EPS dan Inflasi mampu digunakan sebagai alat estimasi harga saham.

\section{Uji Signifikansi Parsial (Uji t)}

Uji signifikansi parsial (Uji t) digunakan untuk mengetahui adanya pengaruh masingmasing variabel independen terhadap variabel dependennya. Kriteria pengambilan keputusan ialah jika nilai signifikansi lebih kecil dari 0,05 maka Ho ditolak dan Ha diterima.

Tabel 7. Hasil uji t

\begin{tabular}{|c|c|c|c|c|c|c|}
\hline & & & Coefficients & & & \\
\hline & & $\begin{array}{r}\text { Unstan } \\
\text { Coeff }\end{array}$ & $\begin{array}{l}\text { rdized } \\
\text { ients }\end{array}$ & $\begin{array}{l}\text { Standardized } \\
\text { Coefficients }\end{array}$ & & \\
\hline & & $\mathrm{B}$ & Std. Error & Beta & $\mathrm{t}$ & Sig. \\
\hline 1 & (Constant) & 924.467 & 6278.084 & & .147 & .885 \\
\hline & ROA & -390.610 & 250.843 & -.232 & -1.557 & .139 \\
\hline & $\mathrm{CR}$ & 2.968 & 3.208 & .092 & .925 & .369 \\
\hline & EPS & 12.766 & 1.557 & 1.030 & 8.200 & .000 \\
\hline & INFLASI & 226.076 & 1962.888 & .014 & .115 & .910 \\
\hline
\end{tabular}

a. Dependent Variable: HARGA SAHAM

Sumber : Data diolah, 2020

Hipotesis 1: Return on Asset berpengaruh terhadap harga saham.

Dari tabel 7 dapat dilihat nilai signifikansi (Sig) variabel ROA sebesar 0,139 lebih besar dari probabilitias ( $\mathrm{Sig}>0,05$ ). Hal ini menunjukkan $\mathrm{H} 0$ diterima dan H1 ditolak, maka dapat disimpulkan bahwa Return on Asset tidak berpengaruh signifikan terhadap harga saham.

Hipotesis 2: Current Asset berpengaruh terhadap harga saham.

Dari tabel 7 dapat dilihat nilai signifikansi (Sig) variabel CR sebesar 0,369 lebih besar dari probabilitias ( $\mathrm{Sig}>0,05$ ). Hal ini menunjukkan $\mathrm{H} 0$ diterima dan $\mathrm{H} 2$ ditolak, maka dapat disimpulkan bahwa Current Asset tidak berpengaruh signifikan terhadap harga saham.

Hipotesis 3: Earning per Share berpengaruh terhadap harga saham.

Dari tabel 7 dapat dilihat nilai signifikansi (Sig) variabel EPS sebesar 0,000 lebih kecil dari probabilitias (Sig < 0,05). Hal ini menunjukkan $\mathrm{H} 0$ ditolak dan $\mathrm{H} 3$ diterima, maka dapat disimpulkan bahwa Earning per Share berpengaruh signifikan terhadap harga saham.

Hipotesis 4: Inflasi tidak berpengaruh signifikan terhadap harga saham. 
Dari tabel 7 dapat dilihat nilai signifikansi (Sig) variabel Inflasi sebesar 0,910 lebih besar dari probabilitias (Sig > 0,05). Hal ini menunjukkan H0 diterima dan H4 ditolak, maka dapat disimpulkan bahwa inflasi tidak berpengaruh signifikan terhadap harga saham.

\section{Koefisien Determinasi}

Koefisien determinasi (R2) mengukur kemampuan variabel independen dalam mempengaruhi variabel dependennya. Besarnya pengaruh variabel independen terhadap variabel dependennya diperlihatkan dari nilai Adjusted $R$ Square. Berdasarkan Tabel 8 diperoleh angka Adjusted $R$ Square sebesar 0,803 atau 80,3\%. Hal ini menunjukkan bahwa persentase sumbangan pengaruh variabel bebas (ROA, CR, EPS dan Inflasi) terhadap variabel terikat (harga saham) sebesar 80,3\%. Atau variabel bebas yang digunakan dalam model mampu menjelaskan sebesar 80,3\% variabel terikat, sedangkan sisanya sebesar 19,7\% dipengaruhi atau dijelaskan oleh variabel lain yang tidak dimasukkan dalam model penelitian ini.

\section{Tabel 8. Hasil uji koefisien determinasi}

\begin{tabular}{ll|r|r|r} 
& & \multicolumn{2}{c}{ Model Summary } \\
Model & R & R Square & $\begin{array}{c}\text { Adjusted R } \\
\text { Square }\end{array}$ & $\begin{array}{c}\text { Std. Error of } \\
\text { the Estimate }\end{array}$ \\
\hline 1 & $.918^{\mathrm{a}}$ & .842 & .803 & 2025.584 \\
\hline
\end{tabular}

a. Predictors: (Constant), INFLASI, CR, EPS, ROA

Sumber : Data diolah, 2020

\section{DISKUSI}

Pada hasil penelitian ini, diketahui bahwa nilai signifikansi sebesar 0,000. Nilai signifikansi tersebut jauh lebih kecil dari 0,05, berarti bahwa ROA, CR, EPS dan Inflasi secara simultan berpengaruh terhadap harga saham.

Berdasarakan hasil pengujian hipotesis variabel Return on Asset secara parsial menunjukkan tidak berpengaruh terhadap harga saham. Hal ini dapat ditunjukkan dengan nilai signifikansi lebih besar dari probabilitas $(0,139>0,05)$. Artinya tidak terdapat pengaruh positif antara Return on Asset terhadap harga saham. Hal ini berarti tidak sesuai dengan perumusan hipotesis awal yang diajukan. Hal ini didukung oleh penelitian yang dilakukan oleh Muktharuddin dan Romalo (2007), Stella (2009) serta Haryuningputri dan Widyarti (2012), yang menyatakan ROA tidak berpengaruh terhadap harga saham. Hasil penelitian ini menunjukkan bahwa dalam berinvestasi investor tidak memperlihatkan ROA sebagai salah satu pertimbangan dalam pengambilan keputusan investasinya karena ROA memiliki kelemahan yang cenderung mengalami fluktuasi naik turun. ROA negatif menunjukkan bahwa total aktiva yang dipergunakan tidak memberikan keuntungan bagi perusahaan/ rugi.

Berdasarakan hasil pengujian hipotesis variabel Current Ratio (CR) secara parsial menunjukkan tidak berpengaruh terhadap harga saham. Hal ini dapat ditunjukkan dengan nilai signifikansi lebih besar dari probabilitas $(0,369>0,05)$. Artinya tidak terdapat pengaruh antara Current Ratio (CR) terhadap harga saham. Hal ini berarti tidak sesuai dengan perumusan hipotesis awal yang diajukan. Hal ini didukung oleh penelitian yang dilakukan oleh Wardani dan Tri Andarini (2016), serta Thrisye dan Simu (2013), yang menyatakan Current Ratio (CR) tidak berpengaruh terhadap harga saham. aset lancar yang bernilai cukup besar yang dalam hal ini digunakan sebagai pembilang dalam perhitungan CR bisa saja lebih didominasi oleh komponen piutang yang tidak tertagih dan persediaan yang belum terjual yang nilai dari kedua 
komponen ini lebih tinggi dari pada nilai komponen aset lancar lainnya yang digunakan untuk membayar utang lancar. Jika hal ini terjadi tentu rasio CR suatu perusahaan akan tinggi dan mengakibatkan seakan-akan perusahaan berada dalam kondisi yang likuid (Wardani dan Tri Andarini, 2016). Hasil penelitian ini juga menunjukkan bahwa informasim perubahan Current Ratio (CR) yang diperoleh dari laporan keuangan tidak berpengaruh pada keputusan atas harga saham pada perusahaan perkebunan kelapa sawit. Hal ini dapat dikarenakan investor dalam melakukan pengambilan keputusan saat investasi tidak memandang penting rasio aktiva lancar dengan hutang lancar yang dimiliki perusahaan.

Berdasarakan hasil pengujian hipotesis variabel Earning per Share (EPS)secara parsial menunjukkan terdapat pengaruh terhadap harga saham. Hal ini dapat ditunjukkan dengan nilai signifikansi lebih kecil dari probabilitas $(0,000<0,05)$. Artinya terdapat pengaruh signifikan antara Earning per Share (EPS terhadap harga saham. Hal ini berarti sesuai dengan perumusan hipotesis awal yang diajukan. Hal ini didukung oleh penelitian yang dilakukan oleh Priatinah dan Prabandaru (2012). Peningkatan pada Earning Per Share (EPS) akan membuat pasar memiliki reaksi yang positif hal ini dikarnakan peningkatan Earning Per Share (EPS) dianggap sebagai sinyal terhadap prosfek perusahaan dimasa yang akan datang. Dengan demikian apabila harga saham perusahaan meningkat maka return yang akan diperoleh investor juga akan semakin tinggi.

Berdasarakan hasil pengujian hipotesis variabel inflasi secara parsial menunjukkan tidak berpengaruh terhadap harga saham. Hal ini dapat ditunjukkan dengan nilai signifikansi lebih besar dari probabilitas $(0,910>0,05)$. Artinya tidak terdapat pengaruh antara inflasi terhadap harga saham. Hal ini berarti sesuai dengan perumusan hipotesis awal yang diajukan. Hal ini didukung oleh penelitian yang dilakukan oleh Wardani dan Tri Andarini (2016) serta Muhammad Husnul, dkk (2017) yang menyatakan inflasi tidak berpengaruh terhadap harga saham. Menurut Tandelilin (2010), flukltuasi inflasi dapat mempengaruhi harga saham. Peningkatan inflasi yang tinggi dapat mengurangi tingkat pendapatan riil yang diperoleh investor dari investasinya. Sebaliknya jika tingkat inflasi suatu negara mengalami penurunan, maka hal ini akan menjadi sinyal yang positif bagi investor seiring dengan turunya risiko daya beli uang dan risiko penurunan pendapatan riil.

\section{KESIMPULAN DAN KETERBATASAN PENELITIAN}

Berdasarkan data yang telah dikumpulkan dan diuji mengenai pengaruh kondisi fundamental dan inflasi terhadap harga saham, menghasilkan kesimpulan bahwa Return On Asset Current Ratio, Earning per Share dan Inflasi secara simultan berpengaruh terhadap harga saham. Return On Asset, Current Ratio dan Inflasi secara parsial menunjukkan tidak berpengaruh terhadap Harga Saham, sedangkan Earning per Share secara parsial menunjukan pengaruh terhadap Harga Saham.

Penelitian ini masih terdapat keterbatasan-keterbatasan yang penting untuk diperhatikan oleh peneliti berikutnya, pertama, yaitu sampel masih terbatas pada perusahaan perkebunan di Bursa Efek Indonesia (BEI), dimungkinkan mengganti dengan perusahaan lain yang lebih luas untuk melihat pengaruh secara signifikan terhadap harga saham. Kedua, dalam penelitian ini peneliti hanya menggunakan data tahunan dengan periode 3 tahun .

\section{DAFTAR PUSTAKA}

Anastasia, N., Gunawan, Y. W., \& Wijiyanti, I. (2003). Analisis Faktor Fundamental Dan Risiko Sistematik Terhadap Harga Saham Properti Di Bej. Jurnal Akuntansi \& Keuangan Vol.5, No.2. 123-132. 
Andes, S,.L., et al. (2017). Pengaruh inflasi, Kurs Rupiah da Suku Bunga terhadap Return Saham Perusahaan Manufaktur. Jurnal akuntansi keuangan dan bisnis, Vol.10, No.2. 816.

Arista, Desy. (2012). Analisis Faktor-Faktor yang Mempengaruhi Return Saham pada Perusahaan Manufaktur yang Go public di BEI periode tahun 2005- 2009, Jurnal Ilmu Manajemen dan Akuntansi. Vol 3 No. 1, Mei 2012.

Budi Purbayu Santosa dan Ashari. (2005) .Analisis Statistik dengan Microsoft Axcel\& SPSS.Yogyakarta. : ANDI.

Brigham, Eugene.F dan Joel F. Houston. (2001). Manajemen Keuangan ( Edisi Kedelapan Buku 2). Jakarta: Erlangga.

Case,K. E. et.al. (2012). Principles of Economics (10 ${ }^{\text {th }}$ edition). United States of America : Pearson Education Limited.

Dewi, Putu \& Suaryana. (2013). Pengaruh EPS, DER, dan PBV terhadap harga saham. E-Jurnal akuntansi universitas udayana, Vol.4 , NO.1. ISSN: 2302-8556. 215-229.

Fahmi, Irham. (2012). Analisis Kinerja Keuangan. Bandung: Alfabeta.

Fahmi, Irham. (2012). Pengantar Pasar Modal. Bandung: Alfabeta.

Haryuningputri, M., Widyarti, E,.T. (2012). Pengaruh rasio profitabilitas dan EVA terhadap harga saham pada sektor industri manufaktur di BEI tahun 2007-2010. Journal of Management, Vol.1, No.2. 67-78.

Husnan, Suad. (2005). Dasar-Dasar Teori Portofolio dan Analisis Sekuritas (Edisi keempat). Yogyakarta: UPP AMD YKPN.

Husnul, Habib,. et all. (2017). Analisis pengaruh inflasi, kurs (IDR/USD), produk domestik bruto dan harga emas dunia terhadap indeks harga saham gabungan (Studi pada Indonesia 2008-2016). Jurnal Administrasi Bisnis, Vol.53, No.1. 66-74.

Jogiyanto. (2008). Teori Portofolio dan Analisis Investasi (Edisi Kelima). Yogyakarta: BPFE.

Hanafi, Mahduh . (2005). Analisis Laporan Keuangan (Edisi 2) . Yogyakarta :UPP AMP YKPN.

Jogiyanto. 2013. Teori Protofolio Dan Analisis Investasi. Yogyakarta: BPFE.

Kartika,H. (2020, Januari 10). IHSG ditutup menguat tipis 0,01\% ke 6,274 pada akhir perdagangan jumat. Kontan.co.id. Diakses dari https://investasi.kontan.co.id/news/ihsgditutup-menguat-tipis-001-ke-6274-pada-akhir-perdagangan-jumat-101.

Kasmir . (2008). Analisis Laporan Keuangan.Jakarta : Rajawali Pers.

Kasmir. (2016). Analisis Laporan Keuangan. Jakarta: Raja Grafindo Persada.

Marfuatun, S.\& Indarti, I. (2012). Pengaruh Earning Per Share, Debt to Equity Ratio, dan Return On Equity terhadap harga Saham Perusahaan LQ-45 di Bursa Efek Indonesia. Aset: Vol. 14 No. 1 M, ISSN 1693-928X . 63-73.

Muktaruddin dan Desmoon King Romalo. (2007). Pengaruh Return On Assets (ROA), Return On Equity (ROE), Return On Investment (ROI), Debt To Equity Ratio (DER), Book Value Per Share (BV) Terhadap Harga Saham Properti di BEJ. Jurnal Penelitian dan Pengembangan Akuntansi, Vol.1, N0.1.69-77.

Nirohito, Vernande. 2009. Analisis Pengaruh Faktor Fundamental dan Risiko Sistematik Terhadap Harga Saham pada Industri Properti dan Real Estate di Bursa Efek Indonesia. Jurnal Akuntansi, Universitas Gunadarma, Jakarta.

Priatinah, D,. \& Kususma, P., A. (2012). Pengaruh Return On Investment (Roi), Earning Per Share (Eps), Dan Dividen Per Share(Dps) Terhadap Harga Saham Perusahaan 
Pertambangan Yang Terdaftar Di Bursa Efek Indonesia (Bei) Periode 2008-2010. Jurnal Nominal, Vol.1, No.2. 50-64.

Prihartini, Ratna. (2009). Analisis Pengaruh Inflasi, Nilai Tukar, ROA, DER dan CR Terhadap Return Saham. Tesis Magister Manajemen, Universitas Diponegoro. Semarang.

Priyatno, Dewi. (2008). Mandiri Belajar SPSS - Bagi Mahasiswa dan Umum. Yogyakarta: MediaKom.

Rafie ,B,T . (2020, Januari 13). Gara-gara pernyataan kontroversial PM Malaysia, outlook saham CPO menarik. Kontan.co.id. Diakses dari https://investasi.kontan.co.id/news/garagara-pernyataan-kontroversial-pm-malaysia-outlook-saham-cpo-menarik?page=all.

Rahardjo, Budi . (2009). Dasar-dasar Analisis Fundamental Saham Laporan Keuangan Perusahaan. Yogyakarta: Gajah Mada University Press.

Setiyawan, Indra. (2014). Pengaruh Current Ratio, Inventory Turnover, Time Interest Earned, dan Return On Equity terhadap harga saham pada perusahaan manufaktur sektor barang konsumsi yang terdaftar di BEI periode 2009-2012. Jurnal Nominal, Vol. 3, No. 35-52. doi: https://doi.org/10.21831/nominal.v3i1.2152.

Sutopo, Yeri., \& Slamet, Achmad. (2017). Statistika Inferensial. Yogyakarta : ANDI.

Sutrisno. (2005). Manajemen Keuangan : Teori, Konsep dan Aplikasi. Yogyakarta : Ekonisia.

Tandelilin, Eduardus. (2010). Portofolio dan Investasi : Teori dan Aplikas (Edisi 1). Yogyakarta: Kanisius.

Thrisye, R,. Y, dan Simu, N. (2013). Analisis Pengaruh Rasio Keuangan Terhadap Return Saham BUMN Sektor Pertambangan Periode 2007-2010. Jurnal Ilmiah Akuntansi dan Bisnis. Vol. 8 No. 2. 75-81.

Wardani,D. K., Andriani,D.F. (2016). Pengaruh kondisi fundamental, inflasi dan suku bunga sertifikat Bank Indonesia terhadap harga saham : Study kasus Perusahaan Real Estate dan property yang terdaftar di Bursa efek indonesi tahun 2010-2013. Jurnal Akuntansi Vol.4, No.2, 77-90.

Badan Pusat Statistik [online]. Diakses 5 Januari 2020 dari http://www. bps.go.id/aboutus.php?inflasi=1

Yahoo Finance [online]. Diakses 5 Januari 2020 dari http:// www.finance.yahoo.com.

Laporan keuangan dan pergerakan harga saham [online]. Diakses 5 Januari 2020 dari http://www.idx.co.id. 